Journal of Teacher Education for Sustainability, vol. 22, no. 2, pp. 49-65, 2020

\title{
Spaced E-learning for Sustainable Education
}

\author{
Janis Kapenieks sen. and Janis Kapenieks jun. \\ Riga Technical University, Riga, Latvia
}

\begin{abstract}
The objective of the research is to determine e-learning solutions for the implementation of the spaced learning in university students' sustainable education. In the spaced e-learning method, the course content includes few-minute pauses between repetitions, during which students let their brain "rest" with different content and then return to the course. Information technology solutions are based on the identification of students' individual and situational interests and the following promotion of students' interests for personal development by the content of spaces. Current research is oriented to the search for benefits from synergy of the technological and pedagogical e-learning developments.

The study includes three cycles of education action research. The first and second cycles aim at finding the most effective method to include content for sustainable personality development in the course. At Riga Technical University, a prototype of two blended learning Master level courses was created and approbated with Master level students. Outcomes of the research were evaluated by reflection on students' opinions and analysis of user behavior data in the e-learning environment OpenEdX.

The results obtained in the first and second cycles of the action research and reflection are the basis for the conceptual development of the Living Lab solution in the MOODLE environment with personalized content. Technological solutions for the implementation of personalized content of spaces for personality development are based on the student's self-assessment of his/her individual interests. The research shows the potential of the spaced e-learning for instructional learning and personality development, thus leading to learning for sustainability in the broadest sense as a perspective of pedagogy with inherently sustainable nature, that we denote as "fostering" in the study.

The spaced e-learning method was seriously influenced by the COVID-19 crisis due to the replacement of blended learning with fully online learning.
\end{abstract}

Key words: e-learning, fostering, spaced learning, sustainable education

\section{Introduction}

Human-induced changes in the global ecosystem require a deeper understanding of humans as part of it. COVID19 crisis shows serious deformities in the comprehension of the interaction of human beings with the other species. Ongoing changes in society give way to the possibility to re-think and develop serious movements for a sustainable 
lifestyle in the deepest understanding of it. Human-made deformations currently lead to comprehensive unsustainability. I. Salìte et al. (Salite, Fjodorova, Meihami, et al., 2020) emphasize human-nature relationships and human attitudes as reasons for unsustainability and relevance of understanding of transdisciplinary nature of unsustainability and sustainability as well. The authors identify anthropocentrism as a fundamental basis for individual and global behavior that leads to unsustainability in the relationships between humans and nature. On the other hand, anthropocentrism leads to a "decline in interest among researchers concerning adaptive management approaches, deep ecology, egocentrism, and more holistic perspectives on sustainability". The authors make the assumption that COVID19 should be the last chance for the implementation of the "human education through nature". The floods of technology that are taking over the world make this solution particularly challenging.

Sustainability consumption strongly correlates with the latest developments in the European Union policies. Several regulations and initiatives are aimed at environmentfriendly behavior of the people on all levels - starting from personal attitudes up to the performance of global companies. "Promoting collaboration among higher education institutions, research organizations and companies on climate change, creation of a competence framework to belp develop and assess knowledge, skills and attitudes on climate change and sustainable development" and similar measures are determined by the Green Deal Action Plan (European Commission, 2019). It is not visible that understanding of sustainable education is identified as the reason for most of the ecological disturbances. We assume that facing the deep ecosystemic development of individuals is an essential source for changes in our relationship with nature. In our study we use personality fostering concept to distinguish development in the broadest sense as a perspective of pedagogy with inherently sustainable nature.

Changes in the comprehension of relationships between mankind and the environment give way to serious changes in the vision of education. Professor H. Tuman in an interview with E. Veidemane (Veidemane, 2020) emphasizes the riskiness of the presence of false values in the concept of competence education, which leads to unsustainability of education in the broadest sense. Replacement of deep understanding and comprehension with mystic "competencies" ruins the ability to analyze and generalize, see interconnections and thus to think independently. H.Tuman realizes that the goal of European classical education was a comprehensively developed person, a personality, not only a small gear-wheel in the social mechanism (Veidemane, 2020).

To promote the sustainability of education, in addition to teaching and collaboration of the learners' schools, a vision emerges - the fostering of "active, creative and honest students who need to learn and acquire competencies necessary in a modern changing society, while taking individual needs and abilities into account" (Valackienè \& Kairienè, 2019). The authors of the study realize the school's predisposition to changes determined by self-definition as a cooperating and learning entity. Several studies emphasize the implementation of action research-based instruction not only as a method to improve knowledge acquisition, but also to increase both the teachers' and learners' sustainability outcomes (Meesuk, Sramoon, \& Wongrugsa, 2020). Action research is identified as an approach to recognition of the unsustainability of humans' actions, increasing with the changes in lifestyle of humans during the past decades of the $20^{\text {th }}$ century and nowadays as well. Transdisciplinary action research allows deepening the understanding of "the links with the environment, perception, undifferentiated identity, sustainable and self- 
generating prototype formation in the ecological sustainability relationship between the person and nature" (Salìte, Fjodorova, Iliško, et al., 2020).

The vision of the contemporary school is based on the attitude to each learner as a personality, taking into account individual needs, abilities, putting individual interests at the heart of knowledge acquisition. If we do not see students as passive accumulators of knowledge, the development of personalities is possible only by the mutual relationship between an active school and an active student (Valackiene \& Kairiene, 2019). The transition to online learning makes this relationship a particular challenge. In the case of e-learning, design of the learning management system (LMS) represents the activity of the school.

The rapid development of information technologies over the past decades gives the insidious impression of human omnipotence and the possibility to ignore the needs of the ecosystem. Salite, Fjodorova, Iliško, et al. (2020) emphasize the decrease of the research beyond anthropocentrism, posing new challenges for ESD research within this decade. In such conditions, it is highly challenging for e-learning technology researchers to follow the sustainability requirements of society and nature. Most of the research deals with technological solutions for the delivery of information by the personalized solutions in order to adapt the learning process to the needs of the individual. Such an approach takes into account different aspects of the personality - the learning style (Truong, 2016; Feldman, Monteserin, \& Amandi, 2015), the interests (Walkington, 2013) or the emotional state of the learner (Zagorskis, Kapenieks, \& Gorbunovs, 2019). Such solutions are oriented towards the acquirement of knowledge, skills and competencies, without paying much attention to the development of the student's personality and attitude towards human relations with the environment and nature.

To develop solutions towards sustainable education in an e-learning environment, it is necessary to create technological and pedagogical solutions for the e-learning environment that, in parallel with the effective acquisition of knowledge and skills, ensure formation of attitudes towards nature and understanding of people as a fundamental unit of the natural world. The current study aims at understanding an increase of the sustainable education value by the synergy of the pedagogical and technological solutions compared to pedagogical and technological aspects taken separately.

\section{Spaced E-learning for Sustainable Personality}

It is well known that repeating knowledge improves its acquisition and retention in memory. The first findings about the spacing effect were published in the book "Über das Gedächtnis: Untersuchungen zur experimentellen Psychologie" ("Memory: A contribution to experimental psychology") by German psychologist Hermann Ebbinghaus in 1885. The spaced approach included the first repetition after one hour, the second one after five hours, the third one after one day, the fourth after three days, and so on ... until finally the tenth repetition after about eight months. The method was compared with mass repetition - repeating ten times consecutively. It was found that the spaced learning method was more effective than the mass repetition approach (Ebbinghaus, 1885).

Spaced learning was successfully used to deliver a science course much more efficiently than using conventional learning. That allowed students to achieve well in high-stakes testing. Figure 1 shows a comparison of the normal forgetting curve and the forgetting curve in the case of spaced learning. 


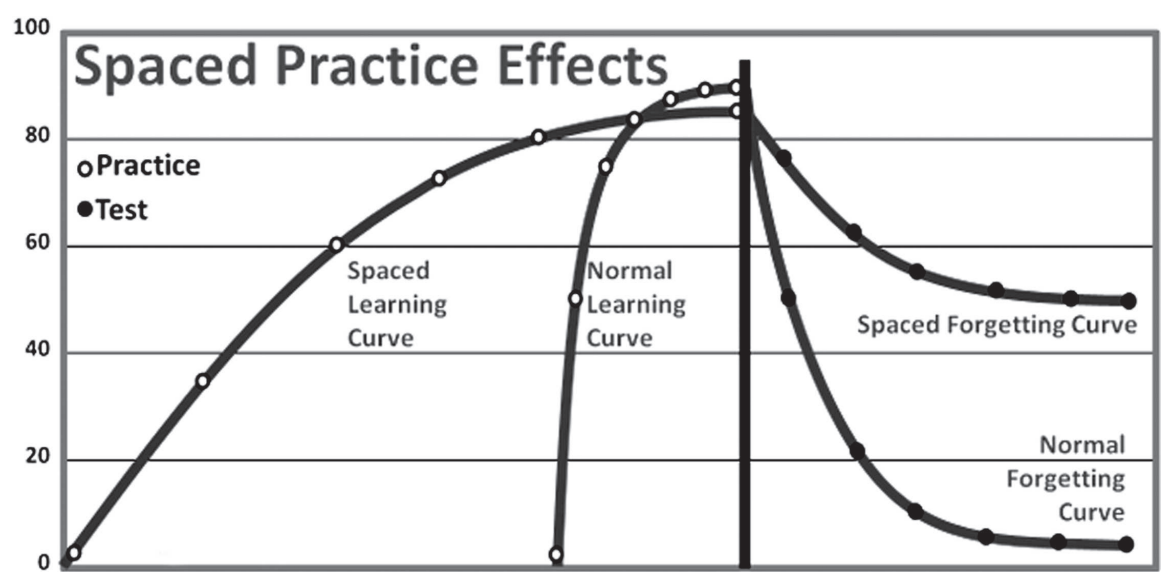

Figure 1. Comparison of the normal and spaced learning forgetting curves (Quinn, 2011)

A more intensive approach to spaced learning is a learning method in which the learning content is repeated several times, with breaks of ten to fifteen minutes during which distractor activities such as physical activities are performed by the learners. Spaced learning is based on a discovery about the brain functionality that was published in 2005 by R. Douglas Fields in Scientific American (Fields, 2005). Fields used a "temporal code" in his experiments, which was developed into a learning method for creating long-term memories by P. Kelley (Kelley, 2007).

The methodology of knowledge retention by the spaced learning method is based on neuroscience findings (Roediger \& Karpicke, 2006; Poldrack, 2010; Roffman et al., 2016), but the key question is the efficiency and methodology of the implementation of the spaced learning method in the case of different epistemological pedagogical approaches, cognitive theories and learning theories. According to the Atkinson-Shiffrin model (Atkinson \& Shiffrin, 1968), at the beginning of the learning process information is processed by the sensory memory - something is perceived through the senses, such as sight, hearing, sensations. Then, it is transferred to the short-term memory or forgotten, depending on how much attention this information has been given to. From the shortterm memory, information is encoded into the long-term memory or forgotten, if encoding is not carried out. Continued rehearsal of information strengthens the memory trace and prevents forgetting.

There are several cases of implementing the spaced approach in e-learning. W. Klemm developed (Klemm, 2012) the short-spaced e-learning method for improvement of the retention of information. W. Klemm's proposal for the design of the spaced e-learning process is based on the research of Kelley and Whatson (Kelley \& Whatson, 2013) (Figure 2).

Experiments by Kelley and Whatson showed that this type of spaced learning was optimal for encoding information and for the activation of genes needed to form longterm memory (Kelley \& Whatson, 2013). As shown in Figure 3, spaces between study periods are short. It is essential that the delivered learning content for repetitions would be in different forms: text, graphics, video, interactive objects, examples, educational games. 


\section{Single-session Spaced Learning Pattern}

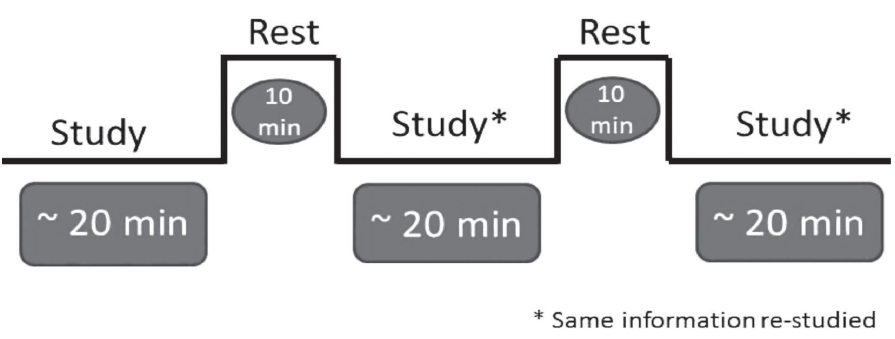

Figure 2. Spaced learning pattern according to W. Klemm (Klemm, 2012)

Development of the methodology by integration of the spaced learning pedagogical benefits with technological solutions in the e-learning environment creates the opportunity to add value to the educational process in two ways: (1) decreasing the total learning time and (2) students' involvement in the development of their individual interests, thus facilitating the transition from unsustainable to sustainable education.

\section{Interests as the Facilitator of Personality Development}

Spaced learning is a powerful method for improving the acquisition and comprehension of knowledge. On the other hand, this approach could be used to motivate learners for sustainability-oriented fostering of the individual. If the content of spaces attracts attention in an exciting way, it leads to deeper interest in the topics oriented to a sustainable worldview. To reach the goal, the content will be closely linked to the learner's interest and it must motivate deeper studies of the topic. Early scientific inquiry of the role of interest in learning started with Dewey's thoughts (Dewey, 1966). A. Krapp (Krapp, 1999) assumed that an object of interests could be referred to the content of cognitively represented life-space: concrete things, a topic, a subject matter, an abstract idea, or others. The authors consider interest to specify intrinsic learning motivation. Situational interestingness and motivational effect (long-lasting preference for a certain topic) can be increased by attractive elements. According to Krapp, situational interest can be actualized by the characteristics of a person and the characteristics of the learning context (Krapp, 1999). I. Korsun studied the dynamics of formation of the learners' interest in physics in the context of sustainability education (Korsun, 2017). His method is based on the following scheme: curiosity - active curiosity - attempts to understand strong knowledge - scientific research. The first step of development starts from the situational interest in the topic. The individual's curiosity about the topic will be characterized by his/her self-evaluated interest or situational interest. Interest is based on prior knowledge and the experience of the individual. It could be a source of powerful motivation for the next step - active curiosity, leading to attempts for a deeper understanding of things. This is the way for a holistic understanding of processes in nature, leading to a transdisciplinary understanding of the world as the basis for sustainable education. Strong knowledge "is associated with volitional efforts of learners and application of knowledge in practice" (Korsun, 2017). Figure 3 shows a flowchart for sustainable fostering of the personality by the spaced e-learning method. 


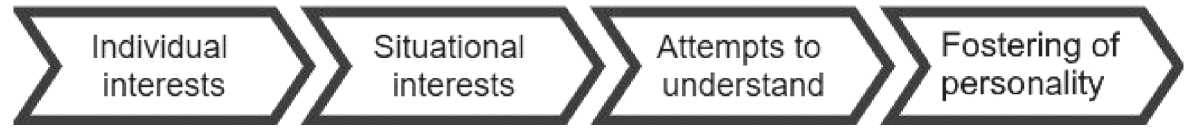

Figure 3. Personality fostering through individual interests

Personalization of the spaced e-learning in accordance with the learner's interest is a starting point for the creation of active curiosity to holistic comprehension and the desire for deeper knowledge. Such considerations are taken into account when we design the spaced e-learning environment.

\section{Spaced E-learning Action Research}

Educational action research is based on J. Dewey's philosophy, created at the end of $19^{\text {th }}$ century (Dewey, 1966). The action research (AR) approach corresponds to the e-learning challenges of today - a motivation of all involved participants, i.e., students, educators, and researchers. Dewey's philosophy is shown as the prerequisite for designing the contemporary educational tools, emphasizing the development of the personality, personalization and student-centeredness on knowledge acquisition (J. Kapenieks \& Salite, 2012).

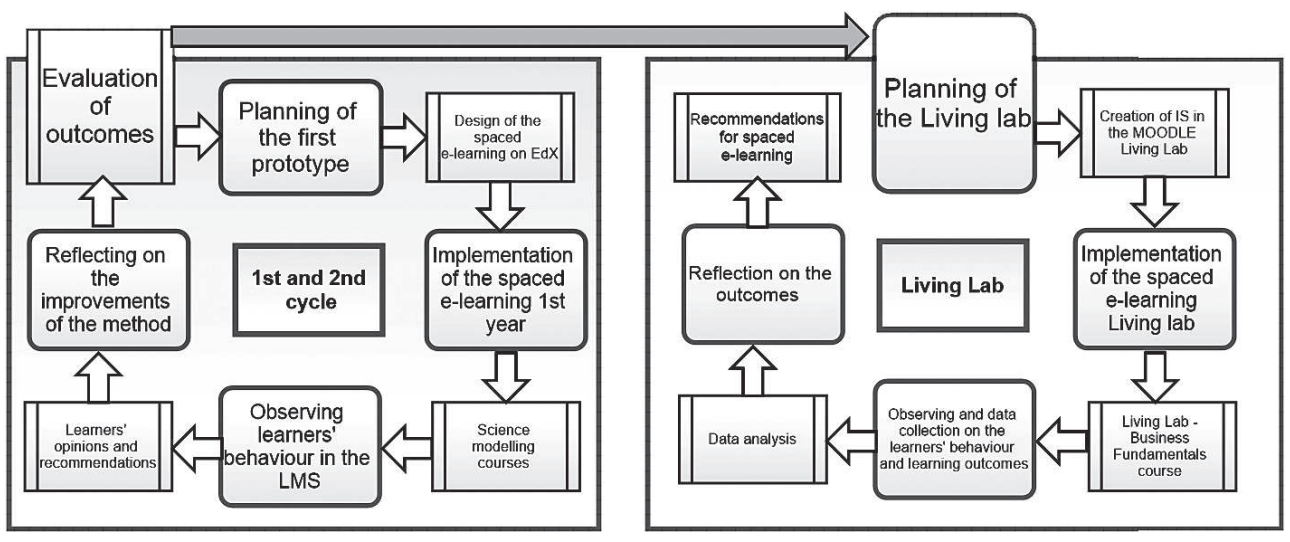

Figure 4. Spaced e-learning implementation and research action research cycles

Research of spaced e-learning is organized as three AR cycles, shown in Figure 4. Two cycles consist of the following steps:

1. Planning of the implementation of the spaced e-learning in the course(s).

2. Implementation of the method in the e-learning environment design and the e-learning process.

3. Observing outcomes of the e-learning process:

- Collecting data on the students' opinions on the spaced e-learning;

- Collecting users' behavior data in the e-learning environment;

- Analyzing and evaluating the results of the implementation of the method;

- Taking into account the opinions of other researchers (networking, mobility).

4. Reflecting on the improvements of the method and the improvements in the technological solution. 
The second educational AR cycle includes the planning of the implementation of advanced solutions, based on the experience and reflection on the first AR cycle.

In the current study, AR provides an opportunity to experience the transition from an unsustainable to a sustainable learning process. Analysis of the experience from the integration of the pedagogical approach with a technological solution allows taking decision on the most appropriate solutions for personalization of the content of spaces for development of learners' personality.

The first and second AR cycles include the implementation of the first prototype of the spaced e-learning methodology in the Master level courses in the blended learning in OpenEdX e-learning environment, followed by the observation, collecting learners' behavior data, gaining experience, and reflecting for improvement of the methodology for the next cycle.

Planning of the third AR cycle is based on the reflection of the outcomes of the first and second cycles. The third cycle includes the creation of an advanced information system for personalization of the content of spaces in the learning management system (LMS) Moodle. The third action research cycle is Living Lab for testing the effectiveness of the method.

\section{Methodology for Implementation of Sustainable Spaced E-learning}

Blended learning in the first and second action research cycles was implemented as discussion in the classroom on the content and exercises acquired in the e-learning environment OpenEdX. The introduction to each section of the course was performed as faceto-face lessons. Classroom presentations of the tasks and discussions were given in face-to-face lessons as well. In the face-to-face classes, the lecturer assessed the knowledge and skills of the students. During COVID-19 restrictions in the second action research cycle, face-to-face lectures were replaced by online seminars in the ZOOM app.

The spaced e-learning course was embedded in the MOOC (Massive Online Open Courses) type e-learning environment OpenEdX. T. Bates (Bates, 2018) assumes that primarily MOOCs aim at the automation of all interactions between the educator and learners. The teaching model focusses on the high-quality transmission of information and computer-based knowledge assessment for feedback from students. The spaced e-learning method aims at achieving the challenging goal - to design the MOOCs type e-learning environment for the development of the learner's personality simultaneously with the improvement of instructional acquisition of the course content, leading to the sustainability goals of learning.

The choice of the content of spaces is most challenging for personalization of the course acquisition and information system design. The first prototype of the spaced e-learning for the Master level 1st year students of Riga Technical University was created by the lecturer. There were the following types of content implemented in the OpenEdX LMS:

1. "Space" without offered content;

2. "Space" with YouTube music video;

3. "Space" with YouTube video about attractive adventures and events;

4. "Space" with YouTube beautiful nature video;

5. "Space" with easy-to-understand additional course material video;

6. "Space" with talking head on an easy-to-understand attractive topic;

7. "Space" with optional additional material on the subject of the course. 
At the beginning of the course, the students' interests are identified by means of a poll in the Google form application. Each section (week) of the course consists of the following stages:

1. An introductory face-to-face lesson on the topic, engaging the students and motivating them to implement active spaced learning with regard to the learning of theory;

2. Quiz for identification of the students' preliminary knowledge of the chapter topic.

3. Unit(s) of theory in different forms of presentation, content of spaces, activation examples, quizzes.

4. Quiz - diagnostic of the acquired knowledge.

Each unit represents some elements of knowledge essential for acquiring the knowledge and skills of the section topic. The conceptual structure of the course unit is shown in Figure 5.

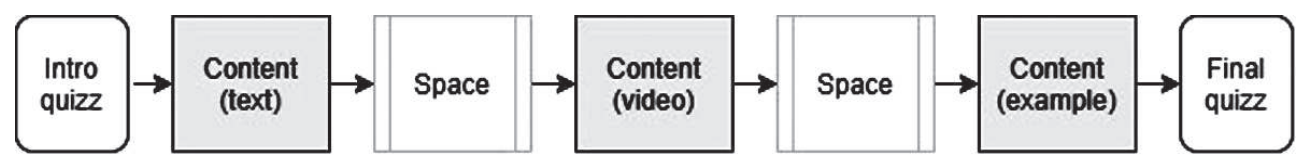

Figure 5. The conceptual structure of the course unit

Spaces are inclusions of engaging content in the course content in the OpenEdX e-learning environment. The length of the spaces is from 4 to 15 minutes, depending on the content.

After the first action research cycle, students' opinions and the lecturer's experience with the design were taken into account. In the second AR cycle, the content of spaces recommended by the lecturer was replaced by the content created or recommended by students. Each student created five to ten minutes of engaging multimedia content, mirroring his/her personal interests on a topic of his/her choice. It is recommended that the theme is related to sustainability. Experience showed that most students were interested in nature and environmental sustainability and preservation issues, which became the topics of their materials. Such topics were "Archives of Latvian Folklore", "Hillforts in Latvia", "Interpretation of Folklore Archive Materials", "Portugal”, "The Latgalian Culture-Between Tradition and Modernity", "Otters" and others. Some students recommended content on the exciting use of information technologies ("The Brave New World of Artificial Intelligence") or topics linked to the subject of learning ("Video Editing and Recreating"). YouTube video or Prezi presentations are the most popular forms for delivery of the engaging content.

\section{Outcomes of the Research during the First and Second Cycles}

During the first action research cycle, the spaced e-learning method was implemented in two blended learning Master level courses for students of Digital Humanities program in the first and second semesters of 2018/2019 and 2019/2020 academic years. Spaced e-learning was implemented in the MOOC type e-learning environment OpenEdX design of Natural Science Modeling and E-pedagogy courses. The study course "Natural Science Modeling" was acquired by 14 and 20 students, respectively, and the study course 
"E-pedagogy" was acquired by 13 and 17 students, respectively. In 2019/2020 academic year, the study course "E-pedagogy" was seriously affected by the COVID-19 crisis, and the course was made fully available online as ZOOM online webinars, conducting theory acquisition in OpenEdX.

There were several essential questions during the implementation of the spaced learning in the e-learning environment:

1. Should the spaces be compulsory or can the student use them voluntarily?

2. What content of spaces do students prefer?

Most students (73\%) preferred to exercise voluntarily spaces in between repetitions of the course content units in different forms after the first cycle of AR. They considered such a method to be more effective. Only $28 \%$ of the students did not oppose mandatory spaces in the course content.

$91 \%$ of the students claimed to have "sometimes" taken breaks during the course and only nine percent of them acknowledged that they had not taken any spaces during acquisition of course content in the e-environment.

If the content of the space is exciting and takes a long watch time, there is a risk that students will be distracted from the course content. $67 \%$ of the students admitted that sometimes after watching entertaining space content, they did not return to the course. $27 \%$ of students said that it never happened.

Students expressed different, sometimes controversial opinions on the effectiveness of the method proposed. Some comments after finishing of the course:

"It's good to have a space!"

"In my opinion, I think the content of each e-learning course should be split into shorter ones, because too much information can make learners lose patience and become distracted. And repeating the same questions in different quizzes is useful, at least for me, I feel it can help me better remember what I "ve learned before."

"The most useful for me were pauses without content, because then I could really "disconnect" from training - my problem is often that I sit on the topic for too long, as a result of which I lose efficiency and the ability to concentrate. Very useful for long-term productivity."

"I think obligatory spaces between materials should be only used at school, kindergarten, not university. At university most of students have already found his/her own pace and optimal learning speed, therefore I think others should not intrude it."

"I think it is tricky to offer these pauses, because, knowing the human mind, a lot of people might not come back to the course. It is evident that the learning material should be divided in short chunks - the problem (or the solution?) is that edx already divides the information into chunks - therefore the learner can take a break when they need and come back to the course when they feel like it."

Controversial opinions on the method shows the need to personalize the method and adapt to each student's learning style and interests.

Students were asked to explain in more detail the rating of the content of spaces. The survey was conducted online two weeks after finishing the course "E-pedagogy". 
Eleven students filled out the Google form in 2019, and only five students answered in 2020 because learning was severely hampered by the COVID-19 crisis. However, the distribution of students provides insight into the students' opinions on the content of spaces (Table 1).

Table 1

\section{Distribution of Students' Opinions in the Evaluation of the Space Content}
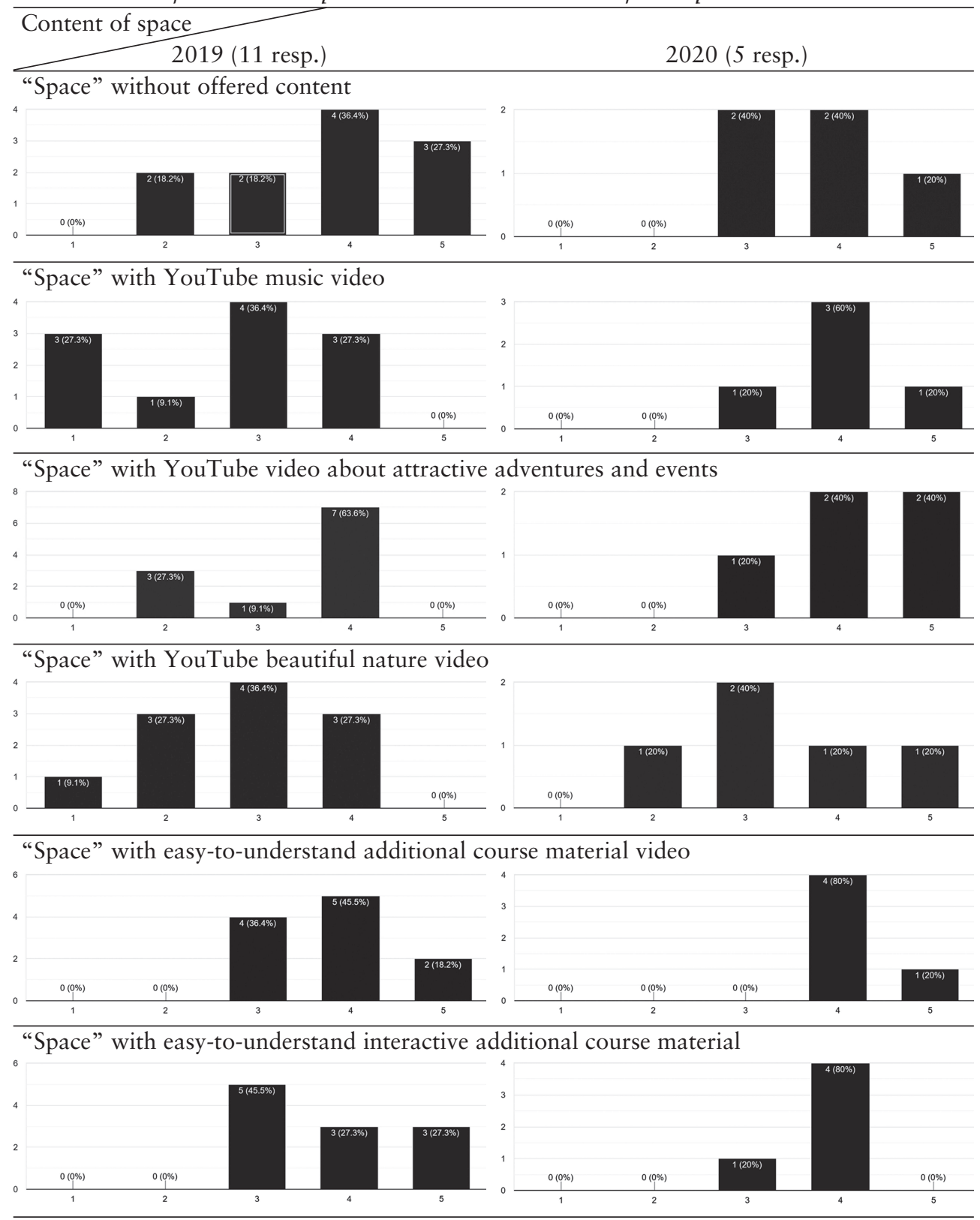

See next page for continuation of table 
Continuation of Table 1
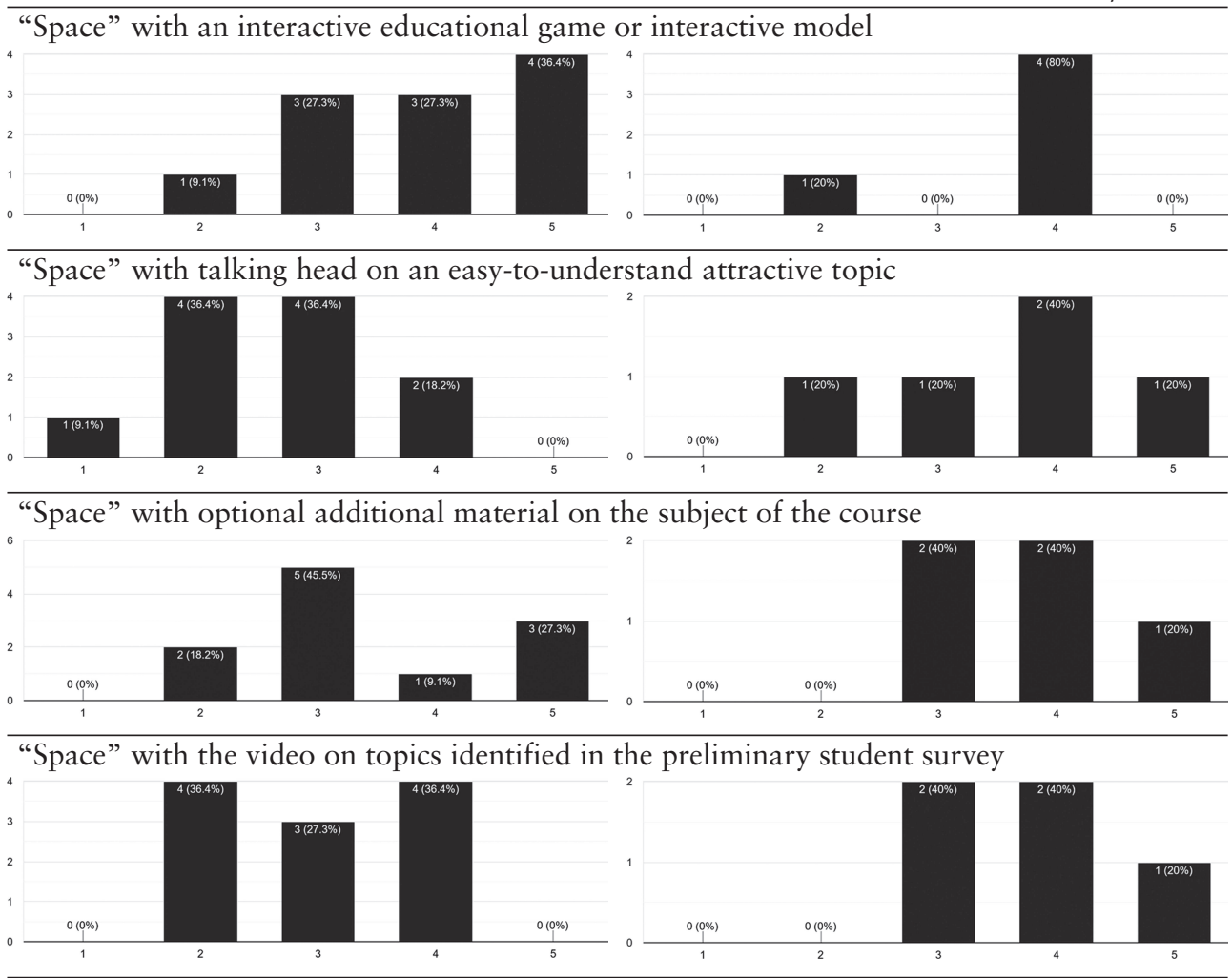

"Space" with interesting material on any topic created by your group members

Was not asked

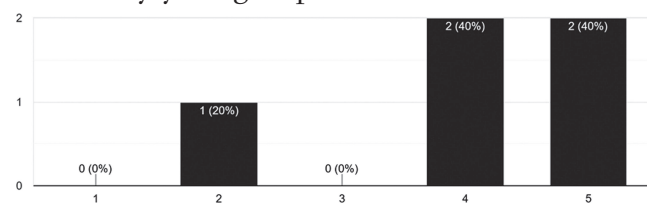

"Space" with interesting material on any topic created by your group members, especially adopted to my interests

Was not asked

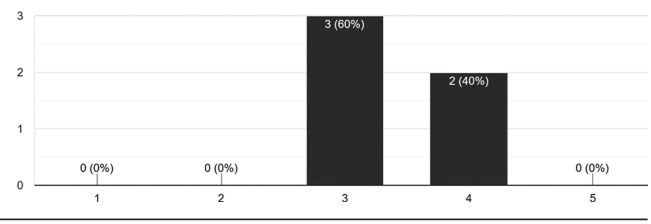

A poll on the content of the spaces shows slight differences in the students' views on the form and content of the spaces. In both cycles, students like spaces without offered content and interactive educational games.

According to the poll, the second-year students prefer entertaining additional course material, entertaining videos or content created by group members in accordance with their interests.

The second-year students highly rated spaces with interesting material on any topic created by their group members. Such content was embedded in the e-environment only 
in the second year. These students did not deny the possibility of embedding interesting material on any topic created by their group members, specially adopted to their interests. Such content was not used in the first and second cycles, but it would be implemented in the third action research cycle.

During the second action research cycle, log files from the OpenEdX environment were collected. OpenEdX log files provided rich information on students' behavior in the e-learning environment.

Log files include information on the date and time, student username, event type, IP address, browser and type of device used, content module identification, and other.

Big data analysis allowed calculating the time spent to watch the videos. For the analysis, three types of videos, recommended as interesting material by students, were chosen:

1) 11-minute engaging YouTube video of general interest "The Brave New World of Artificial Intelligence";

2) 7-minute video "Hillforts in Latvia" dealing with the history and landscape of Latvia, created by a group member;

3) 4-minute YouTube video with optional additional material on the subject of the course "Simpsons Constructivism".

Table 2 shows the activity analysis of the students of the course "E-pedagogy" in 2020, watching the above space contents embedded in the course material. Names of students are coded by letters F (female) or M (male). The column "watch time" shows the total time the content was watched. The column "Clicks" indicates the number of times the student has stopped watching, going deeper into the material. This usually shows a deep interest in the topic.

An extreme decrease in the watch time of the $2^{\text {nd }}$ and $3^{\text {rd }}$ video shows the devastating effects of the COVID-19 crisis on the learning process as it occurred during a state of emergency in the country.

Table 2

Video Watch Time and the Number of Clicks

\begin{tabular}{ccccccc}
\hline Student & $\begin{array}{c}1^{\text {st }} \begin{array}{c}\text { video watch } \\
\text { time }(\min )\end{array} \\
\text { F1 }\end{array}$ Clicks $^{27}$ & 4 & $\begin{array}{c}2^{\text {nd }} \text { video watch } \\
\text { time }(\min )\end{array}$ & Clicks & $\begin{array}{c}3^{\text {rd }} \\
\text { video watch } \\
\text { time }(\mathrm{min})\end{array}$ & Clicks \\
\hline F2 & 12 & 3 & 3.3 & 1 & 2 & 1 \\
\hline F3 & 7.2 & 2 & 3.3 & 1 & 0 & 0 \\
\hline F4 & 12. & 4 & 2.8 & 1 & 11 & 1 \\
\hline F5 & 10. & 3 & 0 & 0 & 0 & 0 \\
\hline F6 & 3.0 & 3 & 0 & 0 & 0 & 0 \\
\hline F7 & 13 & 15 & 0.3 & 0 & 0.2 & 0 \\
\hline M1 & 16 & 3 & 0 & 0 & 0 & 0 \\
\hline M2 & 9.0 & 1 & 0 & 0 & 0 & - \\
\hline M3 & 7.3 & 2 & 0 & - & - & - \\
\hline F8 & 1.8 & 2 & 0 & 0 & 0 & 0 \\
\hline F9 & 10 & 1 & 7.0 & 1 & 1 & 1 \\
\hline F10 & 0.25 & 0 & 0 & 0 & 0 & 0 \\
\hline F11 & 5.0 & 2 & 0 & 0 & 0 & 0 \\
\hline
\end{tabular}


Continuation of Table 2

\begin{tabular}{ccccccc}
\hline F12 & 29 & 3 & 14 & 1 & 0 & 0 \\
\hline F13 & 28 & 2 & 0 & 0 & 5 & 2 \\
\hline F14 & 27 & 2 & 0 & 0 & - & - \\
\hline F15 & 20 & 1 & 0 & 0 & 0 & 0 \\
\hline
\end{tabular}

\section{Reflection on the Outcomes of the First and Second Cycles}

Results of the first and second cycles of the action research showed that most Master level students of Digital Humanities enjoyed using the spaced e-learning method implemented in the blended learning courses "Natural Science Modelling" and "E-pedagogy". When classes were completely transferred online due to the COVID-19 virus social distancing restrictions, some students stopped using the method or did not use it often. This is due to the cognitive overload of the students, as many had to work from home at the same time and to assist their children with online learning.

Implementation of spaces in the e-learning environment between repeating the learning content raised questions on the forms of repeated content and the content of spaces. Varying forms of delivering learning content is a mandatory requirement for the successful implementation of spaced e-learning. The use of textual information, attractive videos, interactivities, and examples make learning attractive. In some cases, watching the content of the space distracted learners from learning. Some students admitted that they also took breaks during acquiring content in regular courses, similar to spaced learning. However, the spaced learning method requires repetition of the course content after the break to strengthen the knowledge in the long-term memory.

In most cases, students support different forms of content of spaces. Some students support a simple reminder to relax for a few minutes. Most, however, find that interesting material makes the break more engaging. In general, students support the delivery of space content in various ways; however, they support entertaining content close to the course material slightly more. Students also support content created by their group members. In this case, each student creates material in the e-environment on a topic of his/her interest in the form of videos, Prezi-presentations, or in other attractive way.

The materials created by students can arouse the students' interest in an important topic for sustainable personal development. It is essential that the material is personalized according to the interests of the student and serves as a starting point for further development. To implement such an approach, it is necessary to create an information system that would ensure personalization of the content of spaces in accordance with the interests of the student. The input data of such an information system would be a self-assessment of the student's personal interests.

These data should be compared with the metadata (keywords) of interesting materials created by the group members. The most relevant materials to meet the students' needs and interests should be included in the content of spaces of the course.

The authors' experience in the first and second cycle of the action research shows that students' interests in most cases are related to acquiring deeper knowledge of nature, science, and ecology. Their materials in the form of videos or presentations can serve as a stimulus for a deeper interest in these topics, leading to the sustainable fostering of personality. To promote the achievement of these goals, the instructor can suggest areas for the creation of interesting materials. 
Personalization of the content of spaces should be implemented in the third action research cycle embedded in the information system and realized as the LivingLab for testing outcomes of the spaced e-learning outcomes.

\section{Conceptual Design of the Third Cycle of Action Research}

In the third AR cycle, spaced learning content is specially adapted to the interests of each student. The technical implementation of the spaced learning idea is based on the custom content generation for each student.

Diagnostic and summative questions at the beginning and end of each unit are added to evaluate the effectiveness of the spaced e-learning using the TELECI method (A. Kapenieks et al., 2020).

From the view of technical implementation, spaced learning functionality is based on adaptive content generation principles. This means that LMS delivers content tailored to the student based on rules defined by the course tutor. Moodle LMS has some in-built functionality providing access control to certain content items. Unfortunately, this functionality did not fit our needs, and the setup of fully functional spaced learning functionality would require a significant amount of manual work. This is why a custom solution was created, integrating Moodle LMS and Google sheets to generate delivery of the spaced learning content through Moodle LMS.

A technological solution was implemented on Moodle 3.9 LMS using internal tools and extra code for better content delivery. The goal of the system was to create a tool capable of injecting custom content in the students' learning content.

It was achieved through a content generator script providing custom content in the form of embedded elements to Moodle LMS on demand. Placeholders for spaced learning elements were inserted among study content elements. These placeholders display spaced learning content generated by the above-mentioned content generator script. To generate content for a student, the script requests data such as the content title and the URL of the embedded element from the Google Sheets API. Currently, student-specific data are stored in Google Sheets, providing a flexible environment for testing different algorithms. The content item is assigned to a student using a set of Google Sheet functions. The system can be adapted to use a database instead of Google Sheets for complete integration in Moodle LMS.

Further work in the third AR cycle is the complete integration of spaced learning in Moodle LMS. This would include further development, providing

1) Moodle feedback module for collecting student data;

2) Custom Moodle LMS plugin for spaced learning content setup and management;

3) Extra tables in the Moodle LMS database for data storage and custom content generation.

The key concept is requirements for the implementation of spaced learning functionality in Moodle LMS for custom content generation for students. This means that Moodle LMS delivers content based on predefined rules. 


\section{Conclusions}

E-learning is a powerful tool for the acquisition of knowledge and skills. Previous experience during the COVID-19 crisis has shown that it is an indispensable set of competency education tools. However, the introduction of competence education has created new risks in pedagogy. A superficial understanding of the concept of competencies may give the impression that the task of education is only to educate and train competent personalities for the labor market. This has already led to the dominance of anthropocentrism and related mercantilism in many sectors of society. The consequences are an unsustainable economy and a way of life that have led to catastrophic changes in the natural environment. The widespread implementation of e-learning methods further increases these risks, as learning environments are designed to deliver information and test knowledge. This opens up a wide field of research on the possibilities of applying the e-learning environment for the implementation of sustainable education, thus developing the individual's personality.

The current research has demonstrated an opportunity to apply the e-learning environment for personal development based on the interests of the student.

The research methods used in the study allow following students' attitudes to spaced e-learning and their activities during the acquisition of the course content. The big data approach allows making a detailed analysis of the students' behavior in the e-learning environment.

Spaced e-learning method requires repeating the same information in different forms using different authoring tools. It allows learning theoretical knowledge, training practical skills and identifying how the knowledge can be used in the real world. Online learners prefer active engagement with the e-learning content rather than passive reading of the theory.

It is important that the content of the spaces is interconnected with the individual interests of students. Encouraging the student within the topic covered by the content of the space can promote deeper understanding of the topic, leading to the fostering development of personality for the sustainable perception of the world in the broadest sense.

The students positively evaluated the use of the method in the course; however, it would not be effective if there was not enough time to learn the subject. During the COVID-19 crisis, students rarely took the opportunity to stop learning a subject before repeating it in another form. Lack of time resulted in the loss of students' interest in the spaced e-learning method.

It is useful to link the engaging content of spaces to the student's individual interests in the third cycle of the action research. Engaging content of spaces can be the source for developing student's individual interests, creating a desire to learn more about the topics of sustainable development, thus leading to personality fostering. Content can be directly or indirectly related to the course objectives. It may also be unrelated to the course objectives.

Personalization of learning is essential in the developed spaced e-learning environment prototype, leading to the collaborative learning prototype based on the students' experience. On the other hand, incorporating a personal interest component into the learning process poses a wide range of challenges to the development of sustainable education and topics for further transdisciplinary research in the fields of pedagogy and information technologies. 


\section{Acknowledgements}

This work has been supported by the European Regional Development Fund within the Activity 1.1.1.2 "Post-doctoral Research Aid" of the Specific Aid Objective 1.1.1 "To increase the research and innovative capacity of scientific institutions of Latvia and the ability to attract external financing, investing in human resources and infrastructure" of the Operational Programme "Growth and Employment" (No.1.1.1.2/VIAA/1/16/156).

\section{References}

Atkinson, R. C., \& Shiffrin, R. M. (1968). Human memory: A proposed system and its control processes (pp. 89-195). In Psychology of learning and motivation, 2. Elsevier.

Bates, A. W. T. (2018). Teaching in a digital age: Guidelines for designing teaching and learning. Retrieved from https://opentextbc.ca/teachinginadigitalage/

Dewey, J. (1966). Democracy and education (1916). Jo Ann Boydston (Ed.), The Middle Works of John Dewey, 9, 1899-1924.

Ebbinghaus, H. (1885). Über das Gedächtnis: Untersuchungen zur experimentellen Psychologie [Memory: A contribution to experimental psychology]. Duncker \& Humblot.

European Commission. (2019). The European Green Deal. European Commission, 53(9), 24. Retrieved from https://doi.org/10.1017/CBO9781107415324.004

Feldman, J., Monteserin, A., \& Amandi, A. (2015). Automatic detection of learning styles: State of the art. Artificial Intelligence Review, 44(2), 157-186. Retrieved from https://doi.org/10.1007/s10462-014-9422-6

Fields, R. D. (2005). Making memories stick. Scientific American, 292(2), 75-81.

Kapenieks, A., Daugule, I., Kapenieks, K., Zagorskis, V., Kapenieks, J., \& Vitolina, I. (2020). TELECI approach for e-learning user behavior data visualization and learning support algorithm. Baltic Journal of Modern Computing, 8(1), 129-142.

Kapenieks, J., \& Salite, I. (2012). Action research for creating knowledge in an e-learning environment. Journal of Teacher Education for Sustainability, 14(2). Retrieved from https://doi.org/10.2478/v10099-012-0012-x

Kelley, P. (2007). Making minds: What's wrong with education and what should we do about it? UK: Routledge.

Kelley, P., \& Whatson, T. (2013). Making long-term memories in minutes: A spaced learning pattern from memory research in education. Frontiers in Human Neuroscience, 7, 589. Retrieved from https:/www.frontiersin.org/article/10.3389/fnhum. 2013.00589

Klemm, W. R. (2012). Memory power 101: A comprehensive guide to better learning for students, businesspeople, and seniors. Skyhorse.

Korsun, I. (2017). The formation of learners' motivation to study physics in terms of sustainable development of education in Ukraine. Journal of Teacher Education for Sustainability, 19(1), 117-128. Retrieved from https://doi.org/10.1515/jtes-20170008

Krapp, A. (1999). Interest, motivation and learning: An educational-psychological perspective. European Journal of Psychology of Education, 14(1), 23-40. Retrieved from https://doi.org/10.1007/BF03173109

Meesuk, P., Sramoon, B., \& Wongrugsa, A. (2020). Classroom action research-based 
instruction: The sustainable teacher professional development strategy. Journal of Teacher Education for Sustainability, 22(1), 98-110. Retrieved from https://doi.org/ 10.2478/jtes-2020-0008

Poldrack, R. (2010). Novelty and testing: When the brain learns and why it forgets. Nieman Reports, 64(2), 9.

Quinn, C. N. (2011). Designing mLearning: Tapping into the mobile revolution for organizational performance. John Wiley \& Sons.

Roediger, H. L., \& Karpicke, J. D. (2006). Test-enhanced learning: Taking memory tests improves long-term retention. Psychological Science, 17(3), 249-255.

Roffman, J. L., Tanner, A. S., Eryilmaz, H., Rodriguez-Thompson, A., Silverstein, N. J., Ho, N. F., ... Abi-Dargham, A. (2016). Dopamine D1 signaling organizes network dynamics underlying working memory. Science Advances, 2(6), e1501672.

Salīe, I., Fjodorova, I., Iliško, D., Ivanova, O., \& Meihami, H. (2020). JTES for sustainable development: An action research environment for the development and sustainable future of the journal identity. Journal of Teacher Education for Sustainability, 22(1), 1-5.

Salite, I., Fjodorova, I., Meihami, H., Ivanova, O., Iliško, D., \& Gholami, J. (2020). JTES approaches to sustainability: Current practices and new perspectives for a more sustainable world. Journal of Teacher Education for Sustainability, 21(2), 14. Retrieved from https://doi.org/10.2478/jtes-2019-0012

Schimanke, F., Ribbers, S., Mertens, R., \& Vornberger, O. (2016). Implications of short term memory research for the design of spaced repetition based mobile learning games. Proceedings - 2015 IEEE International Symposium on Multimedia, ISM 2015, (December), 571-576. Retrieved from https://doi.org/10.1109/ISM.2015.13

Truong, H. M. (2016). Integrating learning styles and adaptive e-learning system: Current developments, problems and opportunities. Computers in Human Behavior, 55, 1185-1193. Retrieved from https://doi.org/10.1016/J.CHB.2015.02.014

Valackiene, A., \& Kairiene, B. (2019). Students' participation in search for sustainability: A case study from Lithuania. Journal of Teacher Education for Sustainability, 21(2), 56-72. Retrieved from https://doi.org/10.2478/jtes-2019-0017

Veidemane, E. (2020). Tumans: Iespējams, mūs gaida civilizācijas gals. Nra.Lv. Retrieved from https://neatkariga.nra.lv/intervijas/324648-tumans-iespejams-mus-gaidacivilizacijas-gals

Walkington, C. A. (2013). Using adaptive learning technologies to personalize instruction to student interests: The impact of relevant contexts on performance and learning outcomes. Journal of Educational Psychology, 105(4), 932-945. Retrieved from https://doi.org/10.1037/a0031882

Zagorskis, V., Kapenieks, A., \& Gorbunovs, A. (2019). Emotions identification utilizing periodic handwriting on mobile surfaces. Periodicals of Engineering and Natural Sciences, 7(1), 228-237. Retrieved from https://doi.org/10.21533/pen.v7i1.355

Correspondence concerning this paper should be addressed to Janis Kapenieks sen., Riga Technical University, Kalku 1, Riga, LV-1658, Latvia. Email: janis.kapenieks@gmail.com 